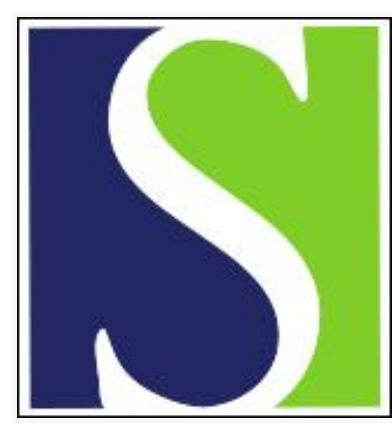

Scand J Work Environ Health 1987;13(5):389-398

https://doi.org/10.5271/sjweh.2022

Issue date: Oct 1987

Assessment of concentration peaks in setting exposure limits for air contaminants at workplaces, with special emphasis on narcotic and irritative gases and vapors.

by Ulfvarson U

Affiliation: Department of Work Science, Royal Institute of Technology, Stockholm, Sweden.

This article in PubMed: www.ncbi.nlm.nih.gov/pubmed/3324319

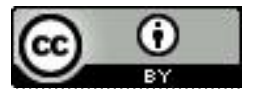




\title{
Assessment of concentration peaks in setting exposure limits for air contaminants at workplaces, with special emphasis on narcotic and irritative gases and vapors ${ }^{1}$
}

\author{
by Ulf Ulfvarson, TechD ${ }^{2}$
}

\begin{abstract}
ULFVARSON U. Assessment of concentration peaks in setting exposure limits for air contaminants at workplaces, with special emphasis on narcotic and irritative gases and vapors. Scand $J$ Work Environ Health 13 (1987) 389-398. In various countries, concentration peaks of gaseous air contamination are assessed by a standard formula. Toxicologic data are not sufficient to warrant occupational short-term exposure limits for the majority of substances. In this article the literature on exposure to concentration peaks is reviewed, and the problem is analyzed from general toxicokinetic and physicochemical points of view. Several ways are suggested to achieve better standards. One straightforward and reasonably simple method is summarized in the following three points, which should be considered in the setting of occupational exposure limits: (i) For substances with fast or moderately fast action, only ceiling limits should be considered; (ii) when structure analogy is justified for narcotic and irritating gases, the correct way is to set the limits at the same thermodynamic activity (relative saturation) of the substances in question and not at the same concentration; (iii) for substances absorbed and eliminated slowly time-weighted exposure limits, combined with rules for excursions, or short-term exposure limits derived from such rules are appropriate, but the possible accumulation of large absolute quantities of the substances should be considered. This point is particularly important when the critical effect is narcosis or irritation, as the thermodynamic equipotency means that the effective concentration of water-soluble gases and vapors is higher than that of substances with low water solubility.
\end{abstract}

Key terms: air contaminants, concentration peaks, limit values, toxicokinetics.

The threshold limit value (TLV) list adopted by the American Conference of Governmental Industrial $\mathrm{Hy}$ gienists (ACGIH) for 1985-1986 (4) (in the rest of this paper the various TLV lists will be referred to by year only) contains the following statement concerning excursion limits for exceeding limit values: "For the vast majority of substances with a TLV-TWA [ = threshold limit value-time-weighted average], there is not enough toxicological data available to warrant a STEL [ $=$ short-term exposure limit $]$. Nevertheless, excursions above the TLV-TWA should be controlled even where the eight-hour TWA is within recommended limits." The quotation states in a nutshell the problem that is to be treated in the following review, ie, there are rules for evaluating varying concentrations of air contaminants, but these rules are, for the most part, general in nature or have been derived from general rules and are not based on scientific data in each individual case. To what extent does the application of these rules protect people from health hazards? It would be a voluminous task to go through the data

1 The article has been prepared and approved, in 1986, as a criterion document within the Nordic expert group for limit-value documentation.

2 Department of Work Science, The Royal Institute of Technology, Stockholm, Sweden.

Reprint requests to: Professor U Ulfvarson, Department of Work Science, The Royal Institute of Technology, S-100 44 Stockholm, Sweden. on every single substance from this standpoint; indeed it would, in many cases, be impossible, since it would require access to the very data that would have been needed to justify short-term exposure limits.

Another approach, which will be used in this review, is to study the manner in which the rules have taken shape and to investigate, through the application of some general lines of reasoning, the consequences of the rules for various groups of substances.

\section{Models of toxicologic effects}

Atherley (7) showed that the concept of the timeweighted average (TWA), as a basis for setting limit values, implies that the toxic effects are proportional to $C T=k$, ie, the product of the exposure concentration $(C)$ and the exposure time $(T)$, where $k$ for a given effect is a constant, this being known as Haber's rule.

In contrast to this concept, it was early shown for a number of hydrocarbons, which typically have a fast to moderately fast rate of elimination, that, if the concentration in air declines, a more than proportional increase in exposure time is required to produce the same narcotic effect. Experimental data for these hydrocarbons better fit the model $C T^{b}=k$, where $b$ is a constant that varies with the substance. Haber's rule is therefore applicable only to substances exhibiting slow elimination. 
A simple explanatory model for the absorption of substances in the form of gases or vapors was developed as far back as the 1920s by Haggard (16) and Henderson \& Haggard (17). It is based on the partition equilibrium between a substance in the inhaled air and the blood passing through the lungs. At equilibrium the quotient between the concentration in the blood, $c_{B}$ (lower-case $c$ to indicate a variable), and the concentration in the inhaled air, $C_{I}$ (capital $C$ to indicate an assumed constant concentration), is $c_{B} / C_{I}=S$, in the following called the partition coefficient. At equilibrium $C_{I}$ is equal to the concentration in the alveolar air. The size of the blood/air or water/air partition coefficient $S$, also known as Ostwald's coefficient, has been determined experimentally and compiled for a number of substances $(14,28$, 44) (table 1). It is also assumed that the average bodily concentration $c$ equals $c_{B}$. The absorption into the body is governed according to the model presented by the following equation (32):

$$
c=c_{B}=C_{I} S\left(1-e^{-k r}\right),
$$

(equation 1)

where $k$ is the elimination constant, which can also be expressed as a function of the half-time $\left(T_{1 / 2}\right)$ : $k=(\ln 2) / T_{1 / 2}$. The value of $k$ is calculated from the partition coefficient and the values, assumed for man, of the alveolar lung ventilation $(\mathrm{eg}, 360 \mathrm{l} / \mathrm{h}$ ), the cardiac output of the heart (eg, $300 \mathrm{l} / \mathrm{h}$ ), and the distribution volume for the substance in the body (eg, 70 1), corresponding to the body volume of an average man, a reasonable assumption in this case (32). On the assumptions given, the biological half-time of the substance will be $T_{1 / 2}=0.135(S+1.2) \mathrm{h}$.

Table 1. Reported values of the waterlair partition coefficient $\mathrm{S}$ at $37^{\circ} \mathrm{C}$ for various organic solvents.

\begin{tabular}{lcl}
\hline Substance & $\begin{array}{c}\text { Partition } \\
\text { coefficient }\end{array}$ & Reference \\
\hline Acetone & 395 & Fiserova-Bergerova (14) \\
Benzene & 263 & Lindqvist (28) \\
& 2.8 & Fiserova-Bergerova (14) \\
Butanol & 4 & Lindqvist (28) \\
Chloroform & 1268 & Lindqvist (28) \\
& 3.5 & Fiserova-Bergerova (14) \\
Carbon tetrachloride & 4 & Fiserova-Bergerova (14) \\
Methylene chloride & 4.5 & Lindqvist (28) \\
& 0.25 & Fiserova-Bergerova (14) \\
Perchloroethylene & 7.2 & Lindqvist (28) \\
1,1,1-Trichloroethane & 7.5 & Ulfvarson \& Ovrum (44) \\
& 0.47 & Ulfvarson \& Ovrum (44) \\
Styrene & 0.93 & Fiserova-Bergerova (14) \\
& 2.9 & Lindqvist (28) \\
& 0.71 & Ulfvarson \& Övrum (44) \\
Toluene & 4.4 & Fiserova-Bergerova (14) \\
& 4.7 & Fiserova-Bergerova (14) \\
Trichloroethylene & 5.2 & Lindqvist (28) \\
& 5.4 & Ulfvarson \& Ovrum (44) \\
o-Xylene & 2.2 & Fiserova-Bergerova (14) \\
\hline & 2.5 & Lindqvist (28) \\
& 1.9 & Ulfvarson \& Ovrum (44) \\
& 1.3 & Fiserova-Bergerova (14) \\
& 1.7 & Fiserova-Bergerova (14) \\
& 2.5 & Lindqvist (28) \\
& 1.6 & Ulfvarson \& Ovrum (44) \\
& 2.6 & Fiserova-Bergerova (14) \\
\hline & & \\
\hline
\end{tabular}

If $S$ is much greater than 1.2, the biological halftime will be directly proportional to $S$ according to the model. If, for instance, $S=100$, then $T_{1 / 2}=14 \mathrm{~h}$, and the time taken to reach $90 \%$ of the equilibrium value - according to the model - will be $45 \mathrm{~h}$, equilibrium not being reached in the course of a workday. When $S$ is on this order of magnitude, $c_{B}$ will increase almost linea ity with time during a workday (the slope $d c / d t$ of equation 1 for small values of $t$ will be a constant, independent of $S$ ), ie, Haber's rule applies if it is assumed that the effect is directly proportional to $c_{B}$ - which is a reasonable assumption in many cases. Thus the model (equation 1) embraces Haber's rule and explains why this rule is applicable only to substances exhibiting slow elimination.

Figures 1 and 2 demonstrate hypothetically what happens according to equation 1 upon absorption into the human body under exposure to either of two different substances at the same average concentration in the air, $28 \mathrm{mg} / \mathrm{m}^{3}(=0.028 \mathrm{mg} / \mathrm{l})$, but in different exposure situations. One substance is assumed to have the low partition coefficient of 1 (typically substances with low water solubility and high vapor pressure). The other is assumed to have the high partition coefficient of 1000 (typically substances with high water solubility and low vapor pressure). In one exposure situation it is assumed that the mean concentration in the air is reached by three half-hour concentration peaks of $0.15 \mathrm{mg} / \mathrm{l}$ in air; the rest of the time the concentration is assumed to be zero (figure 1). In the other exposure situation the concentration in the air is assumed to be constant at $0.028 \mathrm{mg} / \mathrm{l}$ throughout the workday (figure 2). The final result is quite different for the two substances. The substance with the low partition coefficient has a blood concentration close to zero in the first case and of $0.028 \mathrm{mg} / \mathrm{l}$ (the concentration in air) in the second (figure 1). For the substance with the high partition coefficient the blood concentration in both cases is $1.1 \mathrm{mg} / \mathrm{l}$, and the equilibrium value for this substance is not reached during the course of the workday (figures 1 and 2).

The assumption contained in the model is that the biotransformation of the substance in the body is of no significance, that the concentration of lipophilic substances in fatty tissues can be disregarded, and that elimination by other pathways than the lungs is likewise of no significance. This would appear to be a troublesome limitation, but the model holds fairly well for many organic solvents for a short time after the start of exposure, which is confirmed by comparison (reported in reference 44) with published experimental human data covering exposure for $0.5 \mathrm{~h}(1,2)$. On the other hand the model does not apply so well for a longer exposure period or for elimination after the cessation of exposure, but this failure does not prevent it from being suitable for a comparative discussion of what happens during continuous or intermittent exposure to substances possessing very different physical properties. 


\section{History of the time-weighted average and short-term exposure limits}

Occupational exposure limits for air contaminants are nowadays published by a large number of organizations and government agencies in various countries. In a compilation produced in 1980 by the International Labour Office the limit values from 18 countries were brought together (21). Occupational exposure limits for air contaminants have a comparatively long history, which illustrates their meaning and the philosophy behind their development.

In the beginning, the intention was to afford protection from the short-term effects of short-term exposure. In a review, Henschler (18) mentions that limit values were published for the first time by KB Lehmann in Germany. These figures concerned some organic solvents and irritative gases, such as sulfur dioxide and halogens. They were based, among other things, on the author's experiments with one employee in the laboratory. The exposure lasted for $1 \mathrm{~h}$ and was quantified by chemical analysis. The intention was to state the concentration that was just barely tolerable in short-time exposure. Many of Lehmann's figures, based on primitive trials of this kind, were later taken up by Henderson \& Haggard (first published in 1927) (17), and the list was extended by Flury \& Zernik in 1931 (15).



Figure 1. Hypothetical absorption in the human body during exposure to two substances with very different water (or blood) solubility. In this exposure situation the mean concentration of $0.028 \mathrm{mg} / \mathrm{l}$ in the air is reached by three $0.5-\mathrm{h}$ concentration peaks of $0.15 \mathrm{mg} / \mathrm{l}$ of air; the rest of the time the concentration is assumed to be zero.
The most important continued development of limit values took place in the United States, particularly in connection with the ACGIH. The role of the ACGIH in the development of the TLV has recently been elucidated by a volume of reprinted key articles (26) and can also be followed in the forewords to the TLV lists issued annually by the same organization since 1946.

The maximal allowable concentration (MAC) was used for a time in the United States, eg, by the Department of Labor and Industries in Massachusetts and up to 1947 by the ACGIH (8). It was defined as the maximal allowable average concentration to which employees in industry could be exposed for $8 \mathrm{~h}$ daily for a long period without suffering injury or developing an occupational disease $(37,43)$.

In 1957 the MAC concept was redefined by the American Standards Association in terms of the limit under which all variations must be held. However, this association did not publish many limit values, and therefore the definition never gained acceptance (41).

The term threshold limit value (TLV) was defined in the same way as the original term MAC by the ACGIH $(26,43)$, meaning that during an 8 -h period the concentration could be allowed to vary without restriction, as long as the average value did not exceed the set limit.

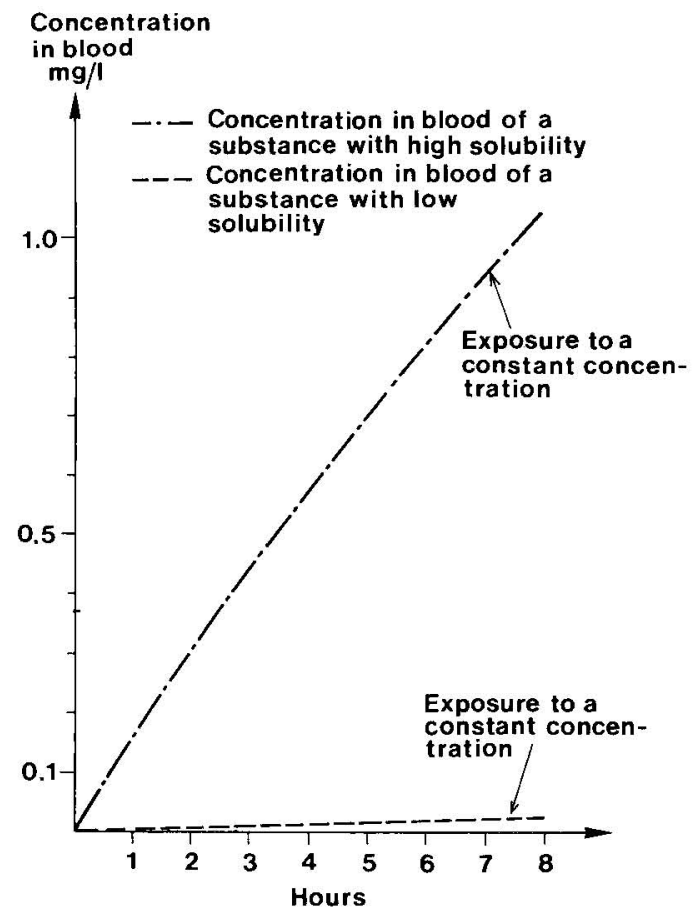

Figure 2. Hypothetical absorption of the same substances as in figure 1 but in an exposure situation where the concentration in the air is assumed to be constant at $0.028 \mathrm{mg} / \mathrm{l}$ throughout the workday. 
Even though this definition was repeated in the forewords to the TLV lists from 1953 on, it took a long time before it became widely understood. In general, the industrial hygienists in the United States interpreted TLV as an upper limit below which all variations in the concentration of an air contaminant had to be held (43). At the same time, questions were raised as to whether it was correct to leave the variations without limits (38). Finally, the ACGIH introduced limitations on short-term concentrations in two ways, by adopting ceiling limits for some substances, applicable during a short part of the workday or shift, and by bringing in "excursion factors," by which the TWA limit values were to be multiplied in order to arrive at values for short-term variations.

Ceiling limits were used for the first time in 1963. To judge whether a ceiling limit was justified for a particular substance, the ACGIH made use of a test factor providing a link to the previously assessed TLV for the calculation of a test concentration. Substances which, at this test concentration, produced (i) intolerable irritation or (ii) chronic or irreversible tissue changes or (iii) a narcotic effect to such a degree that it affected the accident risk, ie, the ability to seek safety, or work capacity were considered to require a ceiling limit (ie, below the test concentration). For substances with a low TLV $\left(0-1 \mathrm{ppm}\right.$ or $\left.\mathrm{mg} / \mathrm{m}^{3}\right)$ the test factor was put at three times the TLV. The factor then declined step by step to 1.25 times the TLV for substances with a high TLV (100-1 000). During 19681980 it was stated in the forewords to the TLV lists that the same factors could be used as excursion factors in calculations of rises above the TLV-TWA, even when no ceiling limit was set.

The reasons for the factor being inversely proportional to the size of the TLV were stated in 1968 to be twofold. On the one hand, large absolute quantities ought to be avoided, and, on the other, small concentrations could not be determined with the same precision as higher ones. These ideas were further developed in 1973 by Stokinger, who stressed the rule-ofthumb character of the excursion factors. The rule was not applicable to some substances that were very irritating to the air passages, whereas it was overly strict for certain other substances, eg, carbon monoxide (42).

In 1976 it was pointed out that there is a difference in the assessment of peak concentrations depending on whether the substance in question acts rapidly or slowly. With quartz, lead, and carbon monoxide, for example, high transient concentration peaks are of no significance (unless they are very high), whereas concentration peaks for quick-acting substances such as hydrogen sulfide, ammonia, sulfur dioxide, and sensitizers had to be assessed by stricter standards.

The sources do not make clear why the ACGIH nevertheless employed the formula-type assessment for limiting concentration peaks. There are a number of penetrating commentaries on this question $(36,38,39)$. Smyth (38) pointed out in 1954 that concentration peaks of some substances had an immediate effect and that TWA concentrations are not serviceable for assessing safety, since even brief excursions above the TLV of some substances can produce irritative symptoms. The same author also made the point that, for $23 \%$ of the substances for which the limit value was assumed to be a safeguard against narcotic effect, the TWA concentration was not applicable (39). The exposure value should not exceed a certain value irrespective of the daily average. The same arguments ought to apply to substances with an irritant effect.

Special short-term exposure limits for 142 substances were published in 1964-1965 and 1967-1969 by the Department of Health in Pennsylvania (30). These limits were applicable for periods of 5,15 , or $30 \mathrm{~min}$. From the published documentation (30) one can draw the conclusion that for many of these substances no safety margin for acute irritation effects or narcotic effects existed at all.

The ACGIH published short-term exposure limits for the first time in 1976. These limits constituted maximal exposure concentrations, defined as the 15-min TWA exposure that must not be exceeded at any time during a workday, even if the exposure falls short of the 8-h TWA. Exposures at the short-term limit must not last longer than $15 \mathrm{~min}$, must not be repeated more than four times a day, and must be separated by intervals of at least $60 \mathrm{~min}$. The shortterm exposure limit is assumed to protect the employee against the same effects as have been described with respect to the ceiling limit values. The short-term limits were based on (i) the adopted TWA-TLV levels, (ii) the aforementioned excursion factors, (iii) the shortterm exposure limits published by the Department of Health in Pennsylvania, and (iv) limit values published by the Occupational Safety and Health Administration (OSHA) in 1971, ie, the TLV levels that were issued by the ACGIH in 1970 and published in the Federal Register (volume 36, number 105, 29 May 1971).

In 1980 the ACGIH introduced a completely different, purely technically based rule for excursions above the TLV. At present (1986-1987), there is a general limit for excursions with the aim of reducing the variability of concentrations of air contaminants to a geometric standard deviation of not more than 2.0. In order to simplify its implementation, it is recommended that the short-term exposure be allowed to exceed not more than three times the TLV for a maximum of 30 min during a workday and that under no circumstances may it reach five times the TLV, all under the assumption that the TWA does not exceed the TLV. According to the committee there is no toxicologic foundation for short-term exposure limits in the case of most substances.

The Federal Republic of Germany defines "Maximale Arbeitsplatzkonzentrationen" - maximum workplace concentrations, abbreviated MAK - in the same way as the TLV according to the ACGIH, meaning that the German MAK committee sets limits for 
the TWA concentrations of substances during a normal 8-h workday. In fact there is close numerical agreement between a large number of the 1984 MAK values and the TLVs that were published in 1984-1985.

However, from 1983 on the German MAK committee has used a completely different method for assessing brief peak concentrations of gaseous air contaminants $(18,19)$. 'This method takes into account the way in which different substances act. Substances are classified into five categories, local irritants being assigned to category 1 , substances having a very weak effect with MAK values above 500 ppm to category 4, and substances with a strong odor to category 5 . For these substances the short-term exposure limit is put at twice the MAK, but with variations in the permitted duration of the exposure periods and varying permissible frequency during the workday or shift.

Categories 2 and 3 contain substances having systemic effects. The short-term exposure limits (STEL) for these substances are fixed with due allowance for the biological half-time of each substance. Substances with a half-time between $2 \mathrm{~h}$ and one workday are given short-term exposure limits corresponding to five times the MAK, while substances with half-times longer than one workday are given short-term exposure limits corresponding to ten times their MAK. The permitted excursion period is $0.5 \mathrm{~h}$ in these cases, while the permitted frequency varies and is smallest for substances with the longest half-time. If the height of the peak concentrations is below the permitted values, the exposure periods can be allowed to last correspondingly longer.

The background to the rules is a model for the absorption and excretion of substances based on firstorder kinetics and simplified assumptions as to the constant concentration of the air contaminant during the time the concentration peak lasts. The basic assumption is that, when a workshift is over, the exposed person will not have taken up more of the substance in his body at various concentrations in the air than he would have done if the exposure had taken place at a constant concentration corresponding to the MAK. This phenomenon is expressed by the following equations (19):

$m\left(T_{\mathrm{STEL}}\right)=(\alpha / \varepsilon)\left(C_{\mathrm{STEL}}\right)\left(1-e^{-\varepsilon T \mathrm{STEL}}\right) \quad$ (equation 2$)$

and

$m\left(T_{\mathrm{MAK}}\right)=(\alpha / \varepsilon)\left(C_{\mathrm{MAK}}\right)\left(1-e^{-\varepsilon T \mathrm{MAK}}\right), \quad$ (equation 3$)$

where $m\left(T_{\mathrm{STEL}}\right)$ and $m\left(T_{\mathrm{MAK}}\right)$ are the absorbed quantity of the substance or metabolite after exposure to the short-term exposure limit or MAK (TWA exposure limit) concentration for the respective times, $\alpha / \varepsilon$ is the quotient of the absorption factor $\alpha$ and the elimination factor $\varepsilon$ (ie, the time constant, $\mathrm{cf}, k$ in equation 1). According to the basic assumption, $m$ ( $\left.T_{\mathrm{STEL}}\right)$ must equal $m\left(T_{\mathrm{MAK}}\right)$. The combination of equations 2 and 3 therefore describes a relationship between the TWA concentration, the peak concen- tration, and the exposure times at the respective concentrations.

The longer the duration of the exposure at the peak concentration, the lower the permissible peak concentration. Empirical values are used for the calculation, but Henschler points out that data are lacking for many substances (19).

Second to Germany, Russia is the country where occupational exposure limits for air contaminants have been in force the longest. Maximal allowable concentrations were published as early as $\mathbf{1 9 2 2}$ for a number of gaseous substances, eg, hydrogen chloride and oxides of nitrogen (35). A number of Russian authors have sought to calculate limit values by using mathematical models making allowance not only for toxicologic data, but also for chemical and physical constants such as boiling point, relative molecular mass, and density $(6,24,25,29)$. The Russian limits are keyed to a measuring period not exceeding $30 \mathrm{~min}(35,40)$. In the case of carbon monoxide, special rules apply to concentration peaks during periods of varying length. A number of aerosols are covered not only by maximal allowable concentrations (ie, during a measuring period of not more than $30 \mathrm{~min}$ ), but also by limit values with respect to average values during a shift (40).

Even though the Russian limits pertain primarily to short-term exposure, they are usually lower than the corresponding TLV levels published by the ACGIH. In a comparison of limits in 1973 it was found that $88 \%$ of the Russian limits was lower than the corresponding values of the ACGIH (22). The explanation for this difference is that the Russian limits are based on other criteria $(20,22,29)$, including sensitive neurophysiological test parameters and biochemical changes during examinations of experimental human subjects, as well as on results from animal experiments. Holmberg \& Winell (20) found that the Russian limits are therefore lower than the corresponding American values from the ACGIH, especially in the case of organic solvents, while on the other hand the limits for irritant and lung-toxic gases and vapors, along with metals and metallic salts, are comparable in the two countries.

\section{Concentration peaks from the toxicokinetic standpoint}

The effect of concentration peaks must be discussed with due regard for the base line from which they depart, ie, the TWA concentration of the substance in question in a certain situation. In the case of highly irritating or quick-acting toxic substances, such as sulfur dioxide, acrolein, phosgene, hydrogen cyanide, and hydrogen sulfide, it is important to limit the concentration even during very short periods, and it has therefore been common practice to fix occupational exposure limits in the form of ceiling limits, with a 
sampling period that is kept as short as the measuring facilities will allow.

As for air contaminants in the form of dusts with low water solubility, elimination from the body after ingestion is slow. A deposit of the dust is built up either in the lungs or during elimination in the particle transport system. The biological half-time of inert or fibrogenous dusts may be $500-10000 \mathrm{~h}$ or more (31). Many dusts containing heavy metals (for example, lead and cadmium), whatever their water solubility, may have a long half-time, owing to absorption in various tissues (31). It has been pointed out by many authors $(31,33,34,45)$ that concentration peaks in the air have



Figure 3. Correlation between 1984-1985 threshold limit values (TLV) of the American Conference Governmental Industrial Hygienists (ACGIH) (5) and vapor pressure in torrs (mm $\mathrm{Hg}, 1$ torr $=133.3 \mathrm{~Pa}$ ) at $25^{\circ} \mathrm{C}(11)$ for a number of organic solvents with mainly narcotic or irritant effects (including fatigue, smell, effects on muscular coordination, and minor organ effects) according to the documentation (4). The numerals refer to the following substances (relative saturation at the TLV in parentheses): $1=$ acetone $(0.003), 2=$ butyl acetate $(0.008)$, $3=$ butyl alcohol $(0.005), 4=$ chlorobenzene $(0.005), 5=$ cyclohexane $(0.002), 6=$ cyclohexanol $(0.02), 7=$ cyclohexanone $(0.004), 8=1,2$-dichloroethylene (cis, trans) (0.0006), $9=$ diethy ether $(0.0006), 10=$ diisopropyl ether $(0.001), 11=$ ethyl alcohol $(0.01), 12=$ ethyl acetate $(0.003), 13=$ ethyl benzene $(0.008)$, $14=$ ethyl butyl ketone (0.03), $15=$ ethylene glycol $(0.4), 16=$ furfuryl alcohol $(0.03), 17=$ heptane $(0.007), 18=$ isoamyl acetate $(0.02), 19=$ isoamyl alcohol $(0.02), 20=$ isobutyl acetate $(0.006)$, $21=$ isophorone $(0.009), 22=$ isopropyl acetate $(0.003)$, $23=$ isopropyl alcohol $(0.007), 24=$ methylcyclohexane $(0.007)$, $25=$ methyl ethyl ketone (0.02), 26 = methyl isobutyl ketone $(0.005), 27=$ methyl propyl ketone $(0.01), 28=$ nonane $(0.03)$, $29=$ octane $(0.02), \quad 30=0$-methyl cyclohexanone $(0.001)$, $31=$ pentane $((0.0009), 32=$ propyl acetate $(0.005), 33=$ propyl alcohol $(0.008), 34=$ sec-butyl acetate $(0.006), 35=$ sec-butyl alcohol $(0.006), 36=$ sec-isoamyl acetate $(0.02), 37=$ tert-butyl alcohol $(0.002), 38=$ toluene $(0.003), 39=$ vinylacetate $(0.0001)$, $40=$ xylene $(0-, \mathrm{m}$-, $\mathrm{p}$ - isomers) $(0.01), 41=1,1,1$-trichloroethane $(0.002), 42=$ tetrachloroethylene $(0.002), 43=$ tetrahydrofurane $(0.0008)$. little or no bearing on the variations in the concentration at the receptor level when the rate of elimination is low. An upper limit to exposure of short duration - a matter of hours - to dust has earlier been advocated on other grounds, such as fouling, effects on vision, effects on the mucous membranes of the eyes and the upper air passages, etc.

Between these extremes, with quick-acting and very potent irritants and highly toxic substances on one side and slow-acting dusts on the other, there is a region in which the assessment of short-duration concentration peaks is complicated. This is true, for example, for most organic solvents and certain inorganic gases such as carbon monoxide, nitric oxide (NO) and nitrous oxide $\left(\mathrm{N}_{2} \mathrm{O}\right)$. TWA limits for an 8-h day combined with rules for excursion above these values are given for most of these substances in the TLV lists of the ACGIH and in other lists of occupational exposure limits that they have inspired, eg, the Swedish list and the German MAK list.

In order to illustrate the levels, a number of organic solvents have been selected from the TLV list of the ACGIH for 1984-1985 among substances that have or have had technical importance. A total of 64 substances was chosen and divided into two groups according to the critical effect or to the "chief site of action," a term employed by the TLV committee of the ACGIH (4). The first group comprises substances having mainly narcotic or irritant effects, according to the TLV documentation (4). They are presented in figure 3. The second group is made up of substances exerting effects on various organs, according to the same documentation (4). They are presented in table 2 .

There is a positive correlation between TLV and vapor pressure, $0.67(0.45-0.78$ at the $95 \%$ level of significance) for the substances in figure 3 . For the substances in table 2 the correlation between TLV and vapor pressure approaches significance, $0.48(0.05-$ 0.75 at the $95 \%$ level of significance).

Considering the correlation between TLV and vapor pressure for the substances in figure 3 , there is reason to suppose a close agreement in relative saturation at the limit value for these substances. The thermodynamic activity of vapors in air is usually expressed, depending on the choice of standard condition, in approximate terms as the relative saturation $p / p_{o}$, where $p$ is the current partial pressure of the substances and $p_{o}$ is the partial pressure at saturation, usually referred to as the "vapor pressure." Most tables of the vapor pressures of substances express them in torrs (mm $\mathrm{Hg})$, so that $p_{\mathrm{TLV}} / p_{o}=\left(760 C_{\mathrm{TLV}}\right) /\left(10^{6} p_{o}\right)$, where $p_{\mathrm{TLV}}$ is the vapor pressure at $C_{\mathrm{TLV}}$, the concentration at the TLV.

The thermodynamic activity (the relative saturation) at the limit value was calculated with vapor pressure figures from reference 11 (see the legend to figure 3 ). For the $\mathbf{4 3}$ substances in figure 3 the thermodynamic activity varies for 30 of the substances between 0.001 and 0.01 and for 22 of these 30 substances within the 
even tighter limits of 0.002 and 0.008 . In the case of these latter substances, the TLV varies from 50 to 750 $\mathrm{ppm}$, ie, the highest value is 15 times the lowest, while the highest activity is only four times greater than the lowest. The substance with the lowest relative saturation at the limit value is vinyl acetate. There is reason to believe that knowledge about its close structural relationship to carcinogenic vinyl chloride has influenced the setting of an occupational exposure limit at a lower level than what is motivated by the medical data referred to in the documentation. Ethylene glycol has the highest relative saturation at the limit value. The high value may be due to the fact that, in sampling air contaminated by this substance, mist is often collected with the vapors.

For the substances with organic effects (table 2), the variability of the thermodynamic activity at the limit value is greater than it is for the narcotic and irritating substances (figure 2), and, on the average, their thermodynamic activities too are lower than for the latter substances. For many substances the limit values have been sharply reduced on one or more occasions. Such action has been taken, for example, for alkoxy ethanols and esters, styrene and hexane, while a num- ber of chlorinated hydrocarbons with systemic effects had low activities at their limit values at quite an early stage.

From the purely technical point of view it is convenient to have a number of organic solvents to choose from that have occupational exposure limits at the same or almost the same thermodynamic activity, since both the limit value and the tendency to evaporate are proportional to the vapor pressure of the substances. If the manufacturer of a given product containing volatile solvents can stay below the limit value with a certain combination of organic solvents in his plant, then he ought to be able to do the same with another combination of solvents. This assumption can be established by the following simple line of argument.

Evaporation obeys Ficks's law of diffusion. A number of more or less empirical equations has been developed to describe the rate of evaporation from sources having different geometries (for instance, according to reference 10). If all circumstances other than the nature of the evaporating substance are kept constant, the emission per unit of time will be proportional to the vapor pressure of the organic solvent. At equilibrium the air concentration, $c$, of the contaminant

Table 2. All-time high threshold limit value $\left(T L V_{h}\right)$ set by the American Conference of Governmental Industrial Hygienists and the final year for this value for a number of organic solvents producing organ effects upon exposure at low concentrations (4). TLV for $1984 / 85$ for the same substances and relative saturation at this value $\left(p_{T L V} / p_{0}\right)$ calculated with vapor pressures $\left(p_{0}\right)$ at $25^{\circ} \mathrm{C}$, taken from The Handbook of Chemistry and Physics (11).

\begin{tabular}{|c|c|c|c|c|c|c|c|}
\hline Substance & $\begin{array}{l}\text { Molecular } \\
\text { weight }\end{array}$ & $\begin{array}{l}\mathrm{TLV}_{\mathrm{h}} \\
(\mathrm{ppm})\end{array}$ & Year & $\begin{array}{c}\text { TLV } \\
\text { (ppm) }\end{array}$ & $\begin{array}{c}p_{0} \\
\text { (torr) }\end{array}$ & $p_{T L V} / p_{o}$ & $\begin{array}{l}\text { Critical } \\
\text { effects }\end{array}$ \\
\hline \multicolumn{8}{|l|}{ Alcohols } \\
\hline Methanol & 32 & 200 & 1985 & 200 & 118 & 0.001 & \multirow{3}{*}{$\begin{array}{l}\text { Dimunition } \\
\text { of vision } \\
\text { Systemic } \\
\text { Testicular } \\
\text { Testicular } \\
\text { (analogy) } \\
\text { Blood changes }\end{array}$} \\
\hline $\begin{array}{l}\text { Allyl alcohol } \\
\text { 2-Methoxy ethanol } \\
\text { 2-Ethoxy ethanol }\end{array}$ & $\begin{array}{l}58 \\
76 \\
90\end{array}$ & $\begin{array}{r}5 \\
100 \\
200\end{array}$ & $\begin{array}{l}1960 \\
1946 \\
1970\end{array}$ & $\begin{array}{l}2 \\
5 \\
5\end{array}$ & $\begin{array}{r}24 \\
6 \\
5\end{array}$ & $\begin{array}{l}0.0001 \\
0.0006 \\
0.0008\end{array}$ & \\
\hline Butoxy ethanol & 118 & 200 & 1956 & 25 & 10.8 & 0.03 & \\
\hline \multicolumn{8}{|l|}{ Esters } \\
\hline $\begin{array}{l}\text { Methyl acetate } \\
\text { 2-Methoxyethyl acetate } \\
\text { 2-Ethoxyethyl acetate }\end{array}$ & $\begin{array}{r}74 \\
118 \\
132\end{array}$ & $\begin{array}{l}200 \\
100 \\
100\end{array}$ & $\begin{array}{l}1985 \\
1946 \\
1980\end{array}$ & $\begin{array}{r}200 \\
5 \\
5\end{array}$ & $\begin{array}{r}210 \\
3 \\
2\end{array}$ & $\begin{array}{l}0.0007 \\
0.001 \\
0.04\end{array}$ & $\begin{array}{l}\text { Systemic } \\
\text { Testicular } \\
\text { Testicular }\end{array}$ \\
\hline \multicolumn{8}{|l|}{ Ketones } \\
\hline Methyl butyl ketone & 100 & 100 & 1975 & 5 & 9 & 0.001 & Neurological \\
\hline \multicolumn{8}{|l|}{ Hydrocarbons } \\
\hline Benzene & 78 & 100 & 1946 & 10 & 96 & 0.0001 & \multirow{2}{*}{$\begin{array}{l}\text { Blood } \\
\text { dyscrasia } \\
\text { Neurotoxic } \\
\text { Tumors }\end{array}$} \\
\hline $\begin{array}{l}\text { Hexane } \\
\text { Styrene }\end{array}$ & $\begin{array}{r}86 \\
104\end{array}$ & $\begin{array}{l}500 \\
400\end{array}$ & $\begin{array}{l}1975 \\
1946\end{array}$ & $\begin{array}{l}50 \\
50\end{array}$ & $\begin{array}{r}150 \\
7\end{array}$ & $\begin{array}{l}0.0003 \\
0.005\end{array}$ & \\
\hline \multicolumn{8}{|l|}{ Chlorinated hydrocarbons } \\
\hline Methylene chloride & 85 & 500 & 1973 & 100 & 440 & 0.002 & \multirow{2}{*}{$\begin{array}{l}\text { Formation of } \\
\text { carbon monoxide } \\
\text { Tumors } \\
\text { Organ effects } \\
\text { Analogy } \\
\text { Hepatic } \\
\text { Neurological, } \\
\text { hepatic }\end{array}$} \\
\hline $\begin{array}{l}\text { Chloroform } \\
\text { Trichloroethylene } \\
\text { 1,1,2-Trichloroethane } \\
\text { Carbon tetrachloride } \\
\text { 1,1,2,2-Tetrachloroethane }\end{array}$ & $\begin{array}{l}119 \\
131 \\
133 \\
154 \\
168\end{array}$ & $\begin{array}{r}100 \\
200 \\
10 \\
100 \\
10\end{array}$ & $\begin{array}{l}1960 \\
1960 \\
1985 \\
1945 \\
1946\end{array}$ & $\begin{array}{r}10 \\
50 \\
10 \\
5 \\
1\end{array}$ & $\begin{array}{r}200 \\
77 \\
24 \\
106 \\
6\end{array}$ & $\begin{array}{l}0.0004 \\
0.0005 \\
0.0003 \\
0.00004 \\
0.0001\end{array}$ & \\
\hline \multicolumn{8}{|l|}{ Miscellaneous substances } \\
\hline $\begin{array}{l}\text { Nitroethane } \\
\text { 2-Nitropropane }\end{array}$ & $\begin{array}{l}75 \\
89\end{array}$ & $\begin{array}{r}200 \\
50\end{array}$ & $\begin{array}{l}1946 \\
1960\end{array}$ & $\begin{array}{r}100 \\
30\end{array}$ & $\begin{array}{l}20 \\
10\end{array}$ & $\begin{array}{l}0.004 \\
0.002\end{array}$ & \multirow{2}{*}{$\begin{array}{l}\text { Hepatic } \\
\text { Gastro- } \\
\text { intestinal } \\
\text { Hepatic, } \\
\text { nephrotoxic }\end{array}$} \\
\hline Dioxane & 88 & 500 & 1946 & 25 & 37 & 0.0005 & \\
\hline
\end{tabular}


will be proportional to the vapor pressure. At the same time the occupational exposure limit $C_{\mathrm{TLV}}$ is proportional to the vapor pressure of the contaminant (ie, the occupational exposure limit is at the same relative saturation for various substances). It thus follows that $c / C_{\mathrm{TLV}}$ is a constant for a number of solvents, ie, is independent of the vapor pressure and is thus independent of the substance being produced. $c / C_{\mathrm{TLV}}$ is sometimes referred to as the "hygienic effect" and may pertain to one substance or to the sum of the quotients of several substances with the same mode of action in the body upon exposure.

The approximate congruence among the "limit value activities" of the narcotic and irritating substances (figure 3 ) is probably not intentional, but is due to the reproducibility of the standard-setting procedure, ie, the fact that in a number of independent investigations the standard setters have found the same level (calculated as thermodynamic activity) for numerous substances. For instance there is nothing to suggest that the TLV committee of the ACGIH has consciously made use of the vapor pressures of the substances in order to gauge the limit values for irritant or narcotic substances. On the contrary, HE Stokinger, the committee's long-time chairman, has stated that the use of vapor pressure in calculating "MAC values" is wholly foreign to the ACGIH and is, in their view, incorrect (29).

The limit values are fixed according to medical criteria, technical and economical feasibility, and industrial experience, and therefore, analogously, similar substances (eg, homologues) are assumed to have similar effects. To the extent that medical criteria have played a part in the fixing of limit values, it may be interesting to compare the outcome with observations of thermodynamic equipotencies among a number of substances that are entirely different, first observed by Ferguson and known as Ferguson's principle (3). One explanation is that the substances act in a structurally nonspecific manner (3), in the case of narcotic substances by "fluidization" of the membranes of nerve cells, owing to the presence of lipophilic substances.

Thermodynamic equipotency has also been demonstrated in animal experiments for a number of alkylbenzenes and aliphatic alcohols whose effect is primarily irritant $(12,23)$. The explanation given by the authors for their observation was that the substances operated through a physical mechanism affecting the trigeminal reflex. In light of their findings the authors propose that TLV levels for irritating substances be put at $3 \%$ of the concentration that reduces the respiration of experimental animals by $50 \%$ or $0.002-$ 0.009 in the case of the alkylbenzenes (cf, the activities for the substances in figure 3 , many of them in the range $0.002-0.008$ ). To avoid misunderstanding, it should be mentioned that alkylbenzenes and aliphatic alcohols are assumed to exert their action in a structurally nonspecific way. Other irritants have lower ther- modynamic activity (relative saturation) at the level of the occupational exposure limit, for example, a number of aldehydes, such as acrolein $\left(3 \times 10^{-7}\right)$, formaldehyde $\left(2 \times 10^{-7}\right)$, and acetic aldehyde $\left(8 \times 10^{-5}\right)$. The fact that these values reflect a particularly high biological potency may indicate that the mechanism of biological action is different (3).

A comparison of the "limit-value activities" of the substances in figure 3 with published data on levels at which measurable effects appear $(9,12,13,23)$ reveals that the safety margins for effects are often small. For the substances in figure 3 , this statement applies in particular to the higher homologues of alcohols, esters, ketones, and hydrocarbons. It may be asked whether this lack of a wide safety margin is the result of the use of "analogous reasoning" in the setting of limits. If the limit for a higher homologue is put at the same volume/volume concentration as that for a lower homologue, then the thermodynamic activity of the higher homologue will be greater since the vapor pressure is lower at the higher molecular weight. In view of this fact, the correct way to apply analogous reasoning - if it is at all justified - would be to set the limits at the same thermodynamic activity of the substances in question.

Another aspect to be considered is that, if a substance has effects other than narcotic ones, including biotransformation, then not only the activity, but also the concentration expressed as moles per kilogram is of interest from the toxicologic standpoint, since the inactivation system of the body is burdened in proportion to the mole concentration. At equilibrium, substances with a high blood/air partition coefficient will have been absorbed to a higher concentration than substances with a low blood/air partition coefficient when the thermodynamic activities are the same. The following reasoning illustrates this point. Substance 1 is assumed to have a vapor pressure of 1 torr and a partition coefficient of 1 . Substance 2 is assumed to have a vapor pressure of 100 torrs and a partition coefficient of 1000 . It is assumed that the occupational exposure limit of both substances, expressed as thermodynamic activity, is 0.005 . After an 8 -h exposure to a steady concentration at the limit value, the blood concentration of the two substances according to equation 1 will be as follows: substance $1=20 \mu \mathrm{g} / \mathrm{l}$, substance $2=80000 \mu \mathrm{g} / \mathrm{l}$. In practice, no substance would satisfy the simple equations for so long a time as $8 \mathrm{~h}$ because of biotransformation and excretion through paths other than pulmonary ventilation, but the difference in the quantity of substance that passes through the body and burdens the inactivition systems can for this reason be still greater than is implied by the calculation.

\section{Conclusions}

Occupational exposure limits for gases and vapors have been developed in different countries in a stereotyped 
manner that makes little allowance for the individual properties of the substances. This development is particularly true with regard to short-term exposure limits. There are not sufficient toxicologic data to warrant occupational short-term exposure limits for the majority of substances. In this article the literature on exposure to concentration peaks is reviewed, and the problem is analyzed from general toxicokinetic and physicochemical points of view.

It would probably not be economically and practically possible to put together sufficient exposure data to permit epidemiologic analysis concerning the effect of short-term exposure for the majority of substances. The greater part of the available exposure data has been collected with the aim of checking on adherence to the rules in force. The measurements are therefore performed in a stereotyped manner. These rules, which have been formulated from inadequate knowledge, have in this way militated against the gleaning of new knowledge.

One way to deal with the situation for many fast or moderately fast acting gaseous substances would be to apply the available toxicokinetic knowledge as described for instance by the German MAK committee $(18,19)$. As this is a rather complicated procedure and the data needed are lacking for many substances, a much simpler route is to define the occupational exposure limits for this kind of substances as ceiling limits. In order to illustrate the consequences of such a step, data from a large number of workplace measurements collated by Leidel and his co-workers (27) can be used. The concentration readings exhibit a logarithmic normal distribution. The geometric standard deviation varies a great deal and shows no regularity. Geometric standard deviations in the range from 1.5 to 2 are common, however. If concentration values in a given situation have a geometric standard deviation of 2.0 , it means that $5 \%$ of all values exceed 3.13 (ie, $\mathrm{e}^{1.645 \ln 2}$ ) times the geometric mean. This figure indicates that the concentration must go substantially below a limit value in many ordinary cases if the probability that the limit will be exceeded is not to become unacceptably great. The matter has been discussed further by Leidel et al (27).

The review and the analysis suggest several ways to achieve better standards for the assessment of concentration peaks. One straightforward and reasonably simple way to deal with the matter is summarized in the following three points, which should be considered in the setting of occupational exposure limits.

1. For substances producing their action fast or moderately fast - in less than an hour - ceiling limits only should be considered. Therefore, not only a number of highly irritating or quick-acting toxic substances such as sulfur dioxide, acrolein, phosgene, hydrogen cyanide, and hydrogen sulfide should be given ceiling limits, but also a number of organic solvents with low water/air partition coefficients (typically lower aliphat- ic and aromatic hydrocarbons and halogenated hydrocarbons with narcosis or irritation as the critical effect) which now have TWA exposure limits.

2. When structure analogy is justified in the setting of occupational exposure limits for narcotic and irritating gases, the correct way is to set the limits at the same thermodynamic activity (relative saturation) of the substances in question and not at the same concentration.

3. For substances which are absorbed and eliminated slowly - a matter of hours or more - timeweighted exposure limits are appropriate, but the possible accumulation of large absolute quantities of the substances should be considered. This point is particularly important when the critical effect is structurally nonspecific narcosis or irritation, as the thermodynamic equipotency of these substances means that the effective concentration in persons exposed to watersoluble gases and vapors is higher than the corresponding concentration of substances with low water solubility.

\section{References}

1. Astrand I. Uptake of solvents in the blood and tissues of man. Scand J Work Environ Health 1 (1975) $199-218$.

2. Åstrand I, Övrum P. Exposure to trichloroethylene: I Uptake and distribution in man. Scand J Work Environ Health 4 (1976) 199-211.

3. Albert A. Selective toxicity. Fourth edition. Methyen \& Co, London 1968.

4. American Conference of Governmental Industrial Hygienists. Documentation of the threshold limit values for chemical substances in the workroom environment. Fourth edition. Cincinnati, OH 1984.

5. American Conference of Governmental Industrial Hygienists. Threshold limit values for chemical substances in the work environment adopted by ACGIH with intended changes for 1985-86 in threshold limit values and biological exposure indices for 1985-86. Cincinnati, $\mathrm{OH} 1985$.

6. Andreesceva NG. Mathematical prediction methods for reflex activity indicative thresholds and maximum allowable concentrations for a single exposure to organic substances in air [in Russian]. Gig Sanit 12 (1977) 58-61. Cited from CIS 78-1366. CISILO 010039. International Labour Office, Geneva.

7. Atherley G. A critical review of time-weighted average as an index of exposure and dose, and of its key elements. Am Ind Hyg Assoc J 46 (1985) 481-487.

8. Bowditch M. Maximum allowable concentration. Division of Occupational Hygiene, Massachusetts Department of Labor \& Industries, Boston, MA 1937. Reprinted in LaNier ME, ed. Threshold limit values - Discussion and thirty-five year index with recommendations. Ann Am Conf Gov Ind Hyg 9 (1984).

9. Brink F, Pasternak JM. Thermodynamic analysis of the relative effectiveness of narcotics. J Cell Comp Physiol 32 (1948) 211-233.

10. Carson BD. Controlling vapor from open surface vessels. Ann Occup Hyg 19 (1976) 313-324.

11. CRC Press Inc. Handbook of chemistry and physics. 59th edition. West Palm Beach, FL 1979.

12. Damgård Nielsen G, Alarie Y. Sensory irritation, pul- 
monary irritation, and respiratory sitmulation by airborne benzene and alkylbenzenes: Prediction of safe industrial exposure levels and correlation with their thermodynamic properties. Toxicol Appl Pharmacol 65 (1982) 459-477.

13. Ferguson $\mathbf{J}$. The use of chemical potentials as indices of toxicity. Proc R Soc London Ser B 127 (1939) $387-404$.

14. Fiserova-Bergerova V, ed. Modelling of inhalation exposure to vapors: Uptake, distribution, and elimination. Volume 1 and 2. CRC Press, Inc, Boca Raton, FL 1983.

15. Flury F, Zernik F. Schädliche Gase. Julius Springer, Berlin 1931 .

16. Haggard HW. The absorption, distribution and elimination of ethyl ether. J Biol Chem 59 (1924) 753-770.

17. Henderson Y, Haggard HW. Noxious gases. Reinhold Publishing Co, New York, NY 1943.

18. Henschler D. Exposure limits: History, philosophy, future developments. Ann Occup Hyg 28 (1984): 1, 79-92.

19. Henschler D. Gesundheitsschädliche Arbeitsstoffe. Toxikologisch-arbeitsmedizinische Begründung von MAK-Werten. 10. Lieferung. Verlag Chemie GmbH Weinheim 1984

20. Holmberg B, Winell M. Occupational health standards: An international comparison. Scand J Work Environ Health 3 (1977) $1-15$.

21. International Labour Office. Occupational exposure limits for airborne toxic substances: A tabular compilation of values from selected countries. Second revised edition. Geneva 1980. (Occupational safety and health series no 37).

22. Izmerov NF. Principles underlying the establishment of air quality standards in the USSR. WHO Chron 28 (1974) 255-260.

23. Kane LE, Dombroske R, Alarie Y. Evaluation of sensory irritation from some common industrial solvents. Am Ind Hyg Assoc J 41 (1980) 451—455.

24. Kettner H. Maximale Arbeitsplatz-Konzentrationen 1978 in der Sovjetunion. Grundlagen der Normierung. Staub 39 (1979): 1, 2-6.

25. Kettner H. Maximale Arbeitsplatz-Konzentrationen 1978 in der Sovjetunion. Grundlagen der Normierung. Staub 39 (1979): 2, 56-62.

26. LaNier ME, ed. Threshold limit values - Discussion and thirty-five year index with recommendations. Ann Am Conf Gov Ind Hyg 9 (1984) 535 p.

27. Leidel NA, Busch KA, Crouse WE. Exposure measurement action level and occupational environmental variability. US Department of Health, Education and Welfare, Cincinnati, OH 1975. (Publication no (NIOSH) 76-131).

28. Lindqvist T. Fördelningskoefficienterna blod/luft och vatten/luft för några vanliga lösningsmedel [The partition coefficients blood/air and water/air for some common solvents]. Arbetarskyddsverket, Stockholm 1977. (Arbete och Hälsa 1977: 8).

29. Magnuson HJ, Fasset DW, Gerarde HW, Rowe VK, Smyth HF, Stokinger HE. Industrial toxicology in the Soviet Union - Theoretical and applied. Am Ind Hyg Assoc J 25 (1964) 185-197. Reprinted in LaNier ME, ed. Threshold limit values - Discussion and thirty-five year index with recommendations. Ann Am Conf Gov Ind Hyg 9 (1984).

30. Pennsylvania Department of Health, Division of Occupational Health. Short-term limits for exposure to airborne contaminants: A documentation, and supplement no 1 to short term limits for exposure to airborne con- taminants. Harrisburg, PA 1967-1969.

31. Rappaport SM. Smoothing of exposure variability at the receptor: Implications for health standard. Ann Occup Hyg 29 (1985): 2, 201-214.

32. Riggs DS. The mathematical approach to physiological problems. The Williams \& Wilkins Co, Baltimore, MD 1963.

33. Rocah SA. A more rational basis for air sampling programs. Am Ind Hyg Assoc J 27 (1966) 1-12.

34. Roach SA. A most rational basis for air sampling programmes. Ann Occup Hyg 20 (1977) 65-84.

35. Roschin AV, Timofeevskaya LA. Chemical substances in the work environment: Some comparative aspects of USSR and US hygienic standards. Ambio 4 (1975): 1, 30-33. Reprinted in LaNier ME, ed. Threshold limit values - Discussion and thirty-five year index with recommendations. Ann Am Conf Gov Ind Hyg 9 (1984).

36. Rowe VK. The significance and application of threshold limit data. Nat Saf Congr 12 (1963) 33-36. Reprinted in LaNier ME, ed. Threshold limit values - Discussion and thirty-five year index with recommendations. Ann Am Conf Gov Ind Hyg 9 (1984)

37. Schrenk HH. Interpretations of permissible limits. Am Ind Hyg Assoc Q 8 (1947): 3, 55-60. Reprinted in LaNier ME, ed. Threshold limit values - Discussion and thirty-five year index with recommendations. Ann Am Conf Gov Ind Hyg 9 (1984).

38. Smyth HF. Toxicological data - Sources of information and future needs. Am Ind Hyg Assoc Q 15 (1954) 203-205. Reprinted in LaNier ME, ed. Threshold limit values - Discussion and thirty-five year index with recommendations. Ann Am Conf Gov Ind Hyg 9 (1984).

39. Smyth HF. A toxicologist's view of threshold limits. Am Ind Hyg Assoc J 23 (1962) 37-43. Reprinted in LaNier ME, ed. Threshold limit values - Discussion and thirtyfive year index with recommendations. Ann Am Conf Gov Ind Hyg 9 (1984).

40. State Standards Committee of the Council of Ministers of the USSR. The system of standards for safety at work: Workplace atmosphere [in Russian]. Moscow 1967 (GOST 12.1.005-76).

41. Stokinger HE. Threshold limits and maximal acceptable concentrations: Definition and interpretation, 1961 Arch Environ Health 4 (1962) 121-123. Reprinted in LaNier ME, ed. Threshold limit values - Discussion and thirty-five year index with recommendations. Ann Am Conf Gov Ind Hyg 9 (1984).

42. Stokinger HE. Industrial air standards - Theory and practice. J Occup Med 15 (1973): 5, 429-431. Reprinted in LaNier ME, ed. Threshold limit values - Discussion and thirty-five year index with recommendations. Ann Am Conf Gov Ind Hyg 9 (1984).

43. Stokinger HE. Threshold limit values. In: Van Nostrand Reinhold. Dangerous properties of industrial materials report. New York, NY 1981, pp 8-13. Reprinted in LaNier ME, ed. Threshold limit values - Discussion and thirty-five year index with recommendations. Ann Am Conf Gov Ind Hyg 9 (1984).

44. Ulfvarson U, Övrum P. Fördelning av lösningsmedel mellan blod och luft [Partition of solvents between blood and air]. Arbetarskyddsverket, Stockholm 1976. (Arbete och Hälsa 1976: 7).

45. Ulfvarson U. Limitations to the use of employee exposure data on air contaminants in epidemiologic studies. Int Arch Occup Environ Health 52 (1983) 285-300.

Received for publication: 9 January 1987 